Conservative Dentistry Journal Vol.8 No.2 Juli-Desember 2018 : 91-95

\title{
EFFICACY OF DIODE LASSER 405 NM WITH CHLOROPHYLLS AS PHOTOSENSITIZER ON Enterococcus faecalis
}

\author{
Sri Kunarti ${ }^{1}$,Amellia Tjandra ${ }^{2}$, Edhie Arif Prasetyo ${ }^{1}$ \\ ${ }^{1}$ Staff of Department Conservative Dentistry \\ Faculty of Dental Medicine - Airlangga University Surabaya - Indonesia \\ ${ }^{2}$ Resident of Department Conservative Dentistry
}

\begin{abstract}
Background: The presence of persistent infections in the root canals by microorganisms causes root canal failure. The most commonly found bacteria that cause persistent infection is Enterococcus faecalis. PDI / photodynamic inactivation is an in vitro approach to inactivation of microorganisms. The combination of light and photosensitivity of chlorophyll in PDI will cause photoinactivation in bacteria. Long radiation of PDT can affect the production of singlet oxygen and ROS (Reactive Oxygen Species) to kill Enterococcus faecalis bacteria. Objective: To prove the effect of $405 \mathrm{~nm}$ laser diode with and without chlorophyll photosensitizer and the irradiation effect of $405 \mathrm{~nm}$ laser diode on the number of CFU of Enterococcus faecalis bacteria. Method: This study used the Enterococcus faecalis bacteria cultur which was divided into 5 groups. Group I as control group, Group II irradiation 30 ', III chlorophyll + irradiation 30', IV irradiation 60 ', V chlorophyll + irradiation 60'. After incubation, the bacteria count was calculated with Quebec Colony Counter and analyzed by Shapiro-Wilk test, Levene test and Anova test. Results: There were significant differences $(p<0.05)$ between the number of colonies of Enterococcus faecalis bacteria in each treatment group. Longer duration of PDT exposure (Group II and IV) with chlorophyll showed less number of Enterococcus faecalis bacteria. Conclusion: The longer the PDT irradiation, the less number of Enterococcus faecalis bacteria. The 60-second radiation with chlorophyll showed the least amount of Enterococcus faecalis bacteria.
\end{abstract}

Keywords: diode laser, chlorophyll, photodynamic therapy, Enterococcus faecalis

Correspondence: Sri Kunarti, Lecture of Departement Conservative Dentistry, Faculty of Dental Medicine, Airlangga University, Surabaya, Indonesia. E-mail: sri-k@fkg.unair.ac.id.

\section{BACKGROUND}

The presence of persistent infections in the root canal by microorganisms causes root canal failure. Bacteria that are commonly found to cause persistent infections are: Enterococcus faecalis, Streptococcus sp, Psudoramibacter alactolyticus, Streptococcus windosus, Bacteroides gracilis, Filifactor alocis and Fusobacterium nucleatum. ${ }^{19}$ Enterococcus faecalis bacteria responsible for $80-90 \%$ of root canal infections. Enterococcus faecalis bacteria have been shown to survive in root canals as single organisms and resistant to commonly used antimicrobial ingredients making it difficult to eliminate from the root canal completely resulting in failure of root canal treatment 16,31 Pathological microorganisms can penetrate the root dentin tubules to a depth of $1000 \mu \mathrm{m}$, while the irrigation disinfection material only reaches $100 \mu \mathrm{m}$ depth. The laser beam penetrates into the dentinal tubule to exceed $1110 \mu \mathrm{m}$ depth for more perfect root canal sterilization, has no toxic content and has a high degree of selectivity to kill bacteria without damaging host cells Photodynamic inactivation or PDI is an in vitro approach to inactivation of microorganisms. The combination of light and certain photosensitiser in PDI will cause photoinactivation in bacteria. The research currently being developed is using 
chlorophyll as an exogenous photosensitiser. The effect of laser diodes as photoinactivation of bacteria is used with endogenous or exogenous photosensitic porphyrins. Each porphyrin molecule has specific light absorption capabilities with specific wavelengths against specific bacteria ${ }^{17}$.

\section{MATERIAL AND METHOD}

The type of this research is laboratory experimental research with Pre-Post Control Only Control Group Design. Sample used in this research is Enterococcus faecalis. Determination of the number of samples used in this study using the Federer formula, obtained the total number of samples as minimum 20. Bacterial culture Enterococcus faecalis done with osse wire that put into a tube containing Brain Heart Infusion (BHI) broth I. Then stirred and incubated $\left(37^{\circ} \mathrm{C}\right)$ in an incubator (48 hours) with an anaerobic atmosphere (Forbes et al., 2002). Then from the tube BHI broth I, was taken 0.5 $\mathrm{ml}$ with micropipette and inserted into the reaction tube containing BHI broth II and synchronized with Mc Farland scale to obtain bacterial suspension 1.5 x $108 \mathrm{CFU} / \mathrm{ml}$. Sampling was obtained from a bacterial suspension reaction tube : $0.5 \mathrm{ml}$ and inserted into each microglass. Group I was a control group (no photosensitiser and no irradiation). Group II irradiation with laser diode light for 30 seconds. Group III is chlorophylls and irradiated for 30 seconds. Group IV irradiation 30 seconds. Group V was given photosensitiser in the form of $0.5 \mathrm{ml}$ of chlorophyll fluid and then irradiated for 60 seconds.

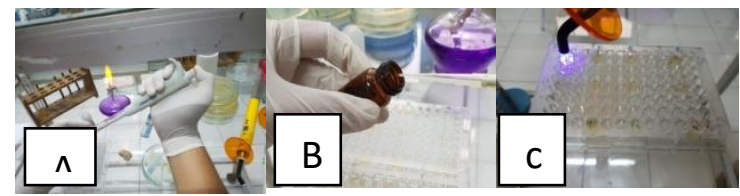

Figure 1. a) E. faecalis culture sampling (b) 0,5 $\mathrm{ml}$ chlorophyll and $0.5 \mathrm{ml}$ Enterococcus faecalis bacteria (c) Irradiation with laser diode according to treatment group

Each microglass is taken $0.1 \mathrm{ml}$ with a micropipette and grown on petridish containing nutrient agar. The petridish contains nutrient agar medium, incubated for 48 hours at $37^{\circ} \mathrm{C}$ in an anaerobic atmosphere.
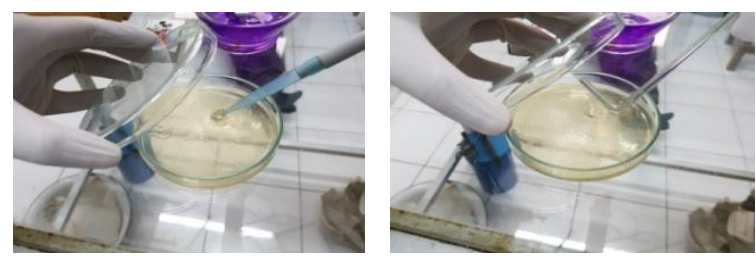

Figure 2. Bacteria Enterococcus faecalis in Nutrient Agar

After incubation, the number of bacterial colonies in petridish was calculated using Quebec Colony Counter by CFU (Colony Forming Unit) method and used for analyzed data ${ }^{4}$.

\section{RESULTS}

From the statistical calculation, the average and standard deviation of the colonies of Enterococcus faecalis bacteria after irradiation was done as Table 5.1.

Table 1: Mean and Standard Deviation Number of Enterococcus faecalis Bacteria After Radiation

\begin{tabular}{|l|l|l|l|}
\hline & N & Mean & $\begin{array}{l}\text { Std. } \\
\text { Deviation }\end{array}$ \\
\hline Kontrol & 7 & 99.14 & 2.035 \\
\hline Biru 30 detik & 7 & 58.71 & 2.059 \\
\hline $\begin{array}{l}\text { Biru 30 detik + } \\
\text { Klorofil }\end{array}$ & 7 & 27.29 & 1.604 \\
\hline Biru 60 detik & 7 & 49.14 & 1.952 \\
\hline $\begin{array}{l}\text { Biru 60 detik + } \\
\text { Klorofil }\end{array}$ & 7 & 18.71 & 2.215 \\
\hline
\end{tabular}

Description: $\mathrm{N}=$ number of samples; Mean = mean; $\mathrm{SD}=$ standard deviation

The resulting data are then tested for normality test with Shapiro-Wilk. Result of normality test all data yield $p$ value $>0,05$. This means that the resulting data has a normal distribution. The data were tested by Levene Test to see the homogeneity of data, Levene Test test showed $p=0,818(p>0,05)$. This shows that the data obtained by each group is homogeneous. An Oneway Anova test is then 
performed to compare the mean of each group and to know the differences between groups. From Oneway Anova test, $\mathrm{p}=0,000(\mathrm{p}<0,05)$ showed that there was significant difference to absorbance of each data group.

The Post hoc Tukey HSD / LSD test is used to compare each group with significant differences and data with no significant differences. The result is that there are significant differences in each group of data obtained $p=0,000(p<0,05)$ as in table below.

Table 2: Tukey HSD test comparison between treatment groups

\begin{tabular}{|l|l|l|l|l|l|}
\hline & Kontrol & 30 & $30+\mathrm{K}$ & 60 & $60+\mathrm{K}$ \\
\hline \multirow{2}{*}{ Kontrol } & & $\mathrm{p}=$ & $\mathrm{p}=$ & $\mathrm{p}=$ & $\mathrm{p}=$ \\
& & $0.000^{*}$ & $0.000 *$ & $0.000 *$ & $0.000^{*}$ \\
\hline \multirow{2}{*}{30} & & & $\mathrm{p}=$ & $\mathrm{p}=$ & $\mathrm{p}=$ \\
& & & $0.000 *$ & $0.000 *$ & $0.000^{*}$ \\
\hline \multirow{2}{*}{$30+\mathrm{K}$} & & & & $\mathrm{p}=$ & $\mathrm{p}=$ \\
& & & & $0.000 *$ & $0.000^{*}$ \\
\hline \multirow{2}{*}{60} & & & & & $\mathrm{p}=$ \\
& & & & & $0.000^{*}$ \\
\hline $60+\mathrm{K}$ & & & & & \\
\hline
\end{tabular}

(Note: $\mathrm{p}<0.05 *=$ significant)

\section{DISCUSSION}

There are three main factors in photodynamics that cause photochemical reactions. Second, there are light absorbing molecules for chemical reactions and molecular absorption depending on the wavelength of light used. And thirdly, the creation of free radicals is reactive to biological systems, causing cell inactivation events. ${ }^{28}$ Each molecule has a light absorption ability that depends on a particular wavelength. The quality and type of molecule used greatly affects the photosensitivity that occurs, so that photodynamic success will be achieved when there is a correspondence between the wavelength of the light source and the photosensitiser. ${ }^{25}$

From the results of the study, the colonies of Enterococcus faecalis bacteria infused with chlorophyll photosensitiser before irradiation with $405 \mathrm{~nm}$ laser diode rays for 30 and 60 seconds showed fewer CFUs when compared to the group without giving chlorophyll photosensitiser. This is due to the role of photosensitiser chlorophyll. Photosensitiser chlorophyll will interact with bacterial cell wall.
Photosensitiser is cation (positively charged), while the bacterial cell wall is anion (negatively charged), from the bonding electrostatic interaction between the photosensitiser material and the bacterial cell wall that releases $\mathrm{Ca} 2+$ and $\mathrm{Mg} 2+$ ions from the cell so that the bacterial cell wall is weaker and its permeability increases. Increased permeability of bacterial cell wall causes the photosensitiser cation to enter the bacterial cytoplasmic membrane, which can lead to increased permeability. This will increase the absorption and binding of photosensitizing cations with bacterial plasma membranes. ${ }^{15}$ The irradiation absorbed by the photosensitiser molecule will result in two stages. In the first stage there will be electron transfer between photosensitiser and substrate and produce radical ion called reactive oxygen species (ROS), superoxide anion (O2-), hydroxyl radical ( $\mathrm{OH}-)$ and hydrogen peroxide $(\mathrm{H} 2 \mathrm{O} 2)$. This ion is highly oxidative to cells. In the second stage, electrons transfer between photosensitiser with oxygen receptors and produce highly reactive and oxidative singlet oxygen. The results of both stages led to the proliferation of bacterial cell membrane proteins, inactivation of NADH enzymes and lactate dehydrogenase, destroying the K-ion balance, destroying bacterial DNA and ultimately inhibiting bacterial growth that ended in cell death. ${ }^{13,15}$

From the results of the research, the colony group of Enterococcus faecalis bacteria irradiation with 60 seconds of light laser diode $405 \mathrm{~nm}$ showed the least number of CFUs compared to other groups this was caused by the use of photosensitiser chlorophyll which play a good role in the absorption process of $405 \mathrm{~nm}$ laser diode, photophysics process described earlier, in addition prolonged exposure can affect the amount of light absorption by photosensitiser to increase energy transfer and generate more ROS and singlet oxygen counts.

\section{CONCLUSION}

There is a long-standing effect of laser irradiation $405 \mathrm{~nm}$ with and without photosensitiser chlorophyll to decrease the number of $E$. faecalis bacteria. There was a 
difference in the amount of E. faecalis bacterial decrease with and without chlorophyll photosensitiser for 30 and 60 seconds, whereas the number of $E$. faecalis bacteria was at least in the $405 \mathrm{~nm}$ laser diode irradiation group with chlorophyll photosensitiser for $60 \mathrm{~s}$

\section{ACKNOWLEDGMENTS}

The authors do not have any financial interest in the companies whose diode lasers materials and laser devices are included in this article.

\section{REFFERENCES}

1. Aneiro, RAS, Nakano RD, Antunes LAA, Ferreira GB, Karla BFC. 2014. Efficacy of Antimicrobial Photodynamic Therapy for Root Canal Infected by E. faecalis. Journal of Oral Science. 56(4): 277-85

2. Anjali Kanwar, HL Usha, N Meena. 2014. The Efficiency of Root Canal Disinfection Using A Diode Laser: in vitro study. Indian Journal of Dental Research. 24. 14-8

3. Astuti, Suryani Dyah. 2011. Potensi Photodinaik Inaktivasi S.aureus dengan endogen photosensitizer pada penyinaran led biru dan merah. Jurnal Berk Panel Hayati. Dep. Fisika Universitas Airlangga. Surabaya: 127-31

4. Bago I, PleckoV, Gabric PD, Schauper Z, Baraba A. 2012. Antimicrobial Effecacy of High Power Diode Laser, Photoactivated Dysinfection, Conventional and Sonic Activated Irrigation during RCT. International Endodontic Journal. 4(2): 9-13

5. Basrani, Bettina dan Malkhassian, Gevik. 2015 Update of Endodontic Irrigating Solutions. Endodontic Irrigation. 5(1): 105-8

6. Bhanu Kotwal, Nanika Mahajan, Vikas Jindal. 2013. Periodontal Disease and Systemic health in Clinical Dentistry. LAMBERT Publishing; 21832

7. Cohen, S. DanHargreaves, K. M. 2016. Pathway of the Pulp. $9^{\text {th }}$ ed. St.Louis.Mosby Elsevier :102, 319-21
8. Dalai, D. R., Bhaskar, D.J., Agali, Blausen., C.,Singh, N. 2014. Modern Concepts of Ultrasonic Root Canal Irrigation. International Journal of Advanced Health Sciences.1(4): 1-4.

9. Federico Foschi, Carla Fontana, Reza Riahi, Karian Ruggiero, Antonio Vera, Philip P. Stashenko. 2007. Photodynamic Inactivation of Enterococcus faecalis in Dental Root Canals in Vitro. Lasers in Surgery and Medicine. 39: 782-7

10. Forbes, B.A., Sahm, D.F, Weissfeld. A.S. 2002. Laboratory Methods for Detection of Antibacterial Resistence, Balley\& Scott's Diagnostic Microbiology. $8^{\text {th }}$ ed. St. Louis.Mosby Inc. Philadelphia: 478.

11. Grossman, Chandra,S., Gopikhrisna, V. Grossman'.2014 Endodontic Practice. $13^{\text {th }}$ ed.Wolters Kluwer : New Delhi. 131-39; 178-236

12. Guffey JS, Wilborn J.2016. In vitro bactericidal effect of $405 \mathrm{~nm}$ and 470 nm Blue Light Photomedicine and Laser Surgery, 24. Arkansas: Phsycal Therapy Plus, HotSprings; 684-8

13. Jimenez L, Fuste M, Garriga A. 2015. Effect of PDT on E. faecalis biofilms. Laser med Sci. 30(1). p: 1519-26

14. Johar Kirpa. 2011. Fundamentals of Laser in Dentistry. London. Jaypee medical Publisher; 81-91

15. Kishen A, Shrestha A. 2015. Photodynamic Therapy for RCT Dysinfection. Endodontic Irrigation. 14(1): 231-52

16. Lins CCSA, Melo ARS, Silva CC, Olivera JB, Lima GA, Castro CCMB. 2015 Photodynamic Therapy Application in Endodontic Aerobic Microorganisme \& Faculttative Anaerobic. Formatex. 2(1): 559-63

17. Lestari, Winda Puji. 2017. Potensi Inaktivasi Streptococcus mutans dengan Penambahan Fotosensitizer Ekstrak Daun Kelor pada Aplikasi Fotodinamik Terapi Light Emitting Diode. Surabaya. Departemen Fisika. Fakultas Sains dan Teknologi. Universitas Airlangga: 98-103 
18. Masato Nagayoshi, Tatsuji Nishihara, Keisuke Nakashima, Shigetsugu. 2011. Bactericidal Effect of Diode Laser Irradiation on E. Faecalis Using Periapical Lession Deffect Model. Internastional Scholarly Research Network. 11:111-17

19. Narasimha Reddy Kanumuru, Rama Subbaiah. 2014. Bacterial Efficacy of Calcium Hydroxide Againts E. faecalis Compared with three Dental Lasers on Root Canal Dentin- An Invitro Study, Journal of Clinical \& Diagnostic Research. 8(11):135-37

20. Nikolaos S \& J. Max Goodson. 2015. Photodynamic therapy in the control of oral biofilms. Periodontology 2000. 55: 143-66. Available from: https://www.researchgate.net/publicatio $\mathrm{n} / 49660782$ Photodynamic therapy in the control_of_oral_biofilms [accessed Jul 1, 2017].

21. Nitzan Y, Divion MS. ALA. 2004. Induced Photodynamic Effect on Gram Positif and Negative bacteria, Journal of Photocem and Photobio. 60-8

22. Njwan F. Shehab. 2014. Recovery Rate of E.faecalis After Er,Cr:YSGG Laser Disinfection of Root Canals: an ExVivo Study.American Journal of Medical and Biological Research.2(1): 12-17

23. Nurdin \& Hermiawati. 2011. Perananan E. faecalis terhadap Persistensi Infeksi Saluran Akar. Bandung: Universitas Padjajaran. 80-5

24. Pandey RK, Zheng G. K.M., Kadish.K.M Smith and Guilard. 2000. Phorphyrins as Photosensitizer in Photodynamic Therapy. The Phorphyrin handbook. Vol 6.

San Diego: Academic Press. 159-60

25. Papageorgious P. 2000. Phototherapy in blue and red light in the treatment of Acne Vulgaris. Brithis Journal Dermatology. 142: 973-78

26. Pradhan Suchetan \& KArnik Rohit. 2013. Laser Endodontic therapy using $940 \mathrm{~nm}$ diode laser. India : Nair Hospital Dental Collage; 201-05

27. Raksa Bhat, Mithra N H, Preethesh Shetty. 2015. Semiconductor Diode
Laser in Disinfection of The Root Canal System in Endodontics. Endodontology. 27(2). p: $158-61$

28. Rusydi, Febdian. 2015. Terapi Fotodinamik: Jendela Unair Menuju Riset Kelas Dunia. Orasi Ilmiah Dies Natalis ke -61. Universitas Airlangga. Surabaya: Universitas Airlangga; 80-90

29. Saidatin, Naili. 2014. Optimasi Paparan Dosis Energi Laser Inframerah Untuk Terapi Fotodinamik Sel Kanker In Vitro dengan penambahan Fotosensitizer. Surabaya. Departemen Fisika. Fakultas Sains dan Teknologi. Universitas Airlangga; 118-24

30. Selma Christina Curry Camargo. 2013. The antibacterial effects of lasers in endodontics. Brazil: University of Cidade. 8-14

31. Suchitra. 2013..Enteroccoccus Faecalis: An Endodontic Pathogen. India: Menipal Collage of Dental Sience; 11-13

32. Sunarko Sinari, 2016. Pemaparan Sinar Dioda 405 nm Pada S. mutans dengan Fotosensitiser Feofitin. Teknobiomedik. Universitas Airlangga. Surabaya

33. Takohiro Immamura, Seiko Tatehara, Yusuke Takebe, Reiko Tokuyama, Tomoko Oshima. 2014. Antibacterial \& Antifungal Effect of $405 \mathrm{~nm}$ Monochromatic Laser on Endodontopathogenic Microorganism. International Journal of Photoenergy. 14: 387-94

34. Tianhong Dai, Beth B. Fuchs, Jeffrey J. Coleman3, Renato A. Prates, Christos Astrakas, Tyler G. St. Denis, Martha S. Ribeiro, Eleftherios Mylonakis, Michael R. Hamblin dan George P. Tegos. 2012. Concepts and principles of photodynamic therapy as an alternative antifungal discovery platform. Front. Microbio. 3:120. Available from: https://doi.org/10.3389/fmicb.2012.0012 $\underline{0}$ [accessed Jul 1, 2017]

35. Walton RE and Rivera EM. 2002. Cleaning and Shaping. In: Walton RE, Torabinejad M.(Eds) Principles and 
Conservative Dentistry Journal Vol.8 No.2 Juli-Desember 2018 : 91-95

Practice of Endodontic. $3^{\text {rd }}$ ed.

Philadelphia: WB Saunders; 206-238 